\title{
Game Using in the Language Education Activities of Children with Mild and Moderate Mental Disabilities
}

\author{
Karla Peter and Viorica Banciu, Member, IACSIT
}

\begin{abstract}
The recovery of children with mental disabilities, regardless of the degree or level of deficiency preoccupied and concern to all professionals involved in the process. Over time there have been numerous attempts to help these children cope better in society continuously changing requirements. Starting from the idea that students with mental deficiency problems in the fields of communication, interpersonal relationships, show their emotions the way we try to show that the improvement difficulties is playing a very important role. We believe that while the students will participate in a series of game-based activities, activities that "will play" being placed in different real life situations, we are able to achieve positive results in their recovery.
\end{abstract}

Index Terms-Mental deficiency, playing, recovery.

\section{INTRODUCTION}

American Association for the Mental delay (deficiency) (1992) defines the mental delay (deficiency) as "mental deficiency refers to substantial limitations in present functioning. It is characterized by below average intellectual functioning existing an important correlation with limitations in two or more adaptive skills. According to Ditrău: communication, self-care, home life, social skills, community use, self-orientation, personal safety and health, leisure and employment theoretical knowledge. Mental delay occurs before the age of 18 [1]

Regarding the classification of mental deficiency, over time there have been so many classifications, mostly considering the value of intelligence quotient (IQ). Regardless of this it was concluded that there are several categories of disability and they are profound or severe mental impairment, severe mental deficiency, mental deficiency moderate mental deficiency slight laminar intellect (the limit). Generally children enrolled in special schools are moderate mental deficiency while those with mild mental disability or those with laminar intellect attempting integration in mainstream schools alongside other students.

In 1963 the U.S. has been designed and implemented some programs that exceeded mere institutionalization of persons with mental retardation directed in two directions: educational interventions designed to train and improve the skills of personal autonomy and social concerns socio- these people work after school [2]. The recovery objectives for people with mental disabilities are:

Manuscript received March 10, 2013; revised May 10, 2013

Karla Peter and Viorica Banciu are with the University of Oradea, Romania (e-mail: karla_barth@yahoo.com, myconferences18@gmail.com).
- Achieving a satisfactory level of personal and social autonomy;

- Developing functional skills and behavioral self-control;

- To acquire knowledge and skills necessary for the provision of a minimum paid employment;

- Defining a proper self-image;

- Strengthening a coherent personality, stable resistant to destabilizing external factors (ambient, social) and internal (personal).

Naturally, not all of these objectives can be achieved if mental deficiency, but in people with mild mental disability they are largely accessible. The basic idea is that there should be subordinated deficiencies objectives, but they must be adapted to the possibilities of real and daily life context in which to integrate. Recovery shall be by learning, psychotherapy and occupational therapy (adding specific activities ludic therapy occupational therapy, stimulation poly-sensorial etc.).

The main forms of making recovery of people with mental disability [3] are:

A-Recovery by learning: Start a form usually held at preschool age and depending on the specific deficiency. Learning will be predominantly emotional and motivational learning accompanied by moral motive and if possible the intellectual.

Social learning - the subject is facing some specific behavioral patterns stimulating the ability to spontaneously imitate. In order to achieve to do this, use as hardeners: reward, praise, promote, stimulate the sense of duty, verbal punishment.

B-The recovery through psychotherapy. Psychotherapy although does not eliminate the disability act positively on the spirit and personality, removes anxiety and negativity, working motivation and impulses become an energizing factor of implying of the subject recuperative process. Through psychotherapy the conflict situations, the feelings of inferiority are removed, reinforcing positive traits, positive motivation.

The forms of psychotherapy are most effective if mental deficiency suggestive psychotherapy and relaxation.

C-Recovery through occupational therapy - can be applied to all categories of disability. The best known and most important forms are: Ludic therapy, art therapy, music therapy, rhythm-therapy, dance therapy, occupational therapy. It is important that applications be adapted to the possibilities subjects to avoid discouragement and loss of interest in relation to work.

What is important for people with disabilities and for those watching their recovery (different types of specialists) is actually achieving positive results to be able to individuals in 
need to live and cope better possible in society, to meet its requirements with the same rights and obligations which would have each one of us.

The game remains the permanent form of mental disabled recovery process because this method is a unitary between stimulus-response-reinforcement modification. [4]

\section{The Methodology ReseARCH}

\section{A. Research Objectives}

- Collecting information on the game and its importance of it in the recovery of children with mental deficiencies;

- The analysis of the communication of children with mild and moderate mental disability scales through observation;

- Designing and implementing a therapeutic program for developing students' communication mild and moderate mental disability which is based on the game

\section{B. Hypothesis}

We assume that the design and implementation of a therapeutic program which is based on the game will improve communication ability of students with mild and moderate mental deficiency.

\section{Sample of Subjects}

As more research was involved 28 students with mental deficiencies from a school center for inclusive education in Oradea, Romania. All students are aged between 8 and 11 years, 12 girls and 16 boys. Of these, according to psychological and psychiatric evaluations 14 have mild mental disability and 14 moderate mental deficient.

\section{Methods Used in Research}

\section{1) Observation}

In order to obtain more accurate data on student observation I made a grid that contains items related to communication behavior of students. They relate to: student's ability to speak correct pronunciation, vocabulary, how he speaks (respectful, hard-whispering) initiative in communication, speaking in the presence of adults, communication with peers. The grid was applied both pretest and posttest by the researchers.

\section{2) Experiment}

It was already known place in stages:

- Pretest - consisting of applying observation scales for the 28 subjects involved in research. Our goal was to identify the level of development where students are in terms of communication.

- Step experienced lasted 12 weeks, first semester of school year 2012-2013, 2 hours a week. Students participated in a series of activities, games in which the focus was on developing their communication. We used the educational games that help develop phonemic hearing ("the train"), games for learning pronunciation (snake and bee, fire and wind) vocabulary games ("I say you say one more, What a bear found?" ).

- Posttest - Pretest replenishment observation grid

\section{E. Analysis and Interpretation of Results}

Below we present the results obtained by students involved in the experiment at some of the items scale of observation. Thus, for the item on the student's ability to speak, important for the purposes of the experiment, the results of students who worked are shown in the following Table I.

TABLE I: STUDENTS’ ABILITY TO SPEAK

\begin{tabular}{|l|l|l|l|l|l|l|l|l|l|}
\hline pretest & \multicolumn{9}{|l|}{} \\
\hline Not at all & less & medium & normal & Very well & Not at all & less & medium & normal & Very well \\
\hline $10 \%$ & $30 \%$ & $50 \%$ & $10 \%$ & $0 \%$ & $6 \%$ & $20 \%$ & $56 \%$ & $18 \%$ & $0 \%$ \\
\hline
\end{tabular}

TABLE II: PRONUNCIATION STUDENTS IN SPEECH PRETEST POSTTEST NOT LESS THAN NORMAL ENVIRONMENT

\begin{tabular}{|l|l|l|l|l|l|l|l|l|l|}
\hline pretest & posttest & less & medium & normal & Very well \\
\hline Not at all & less & medium & normal & Very well & Not at all & less & m & & \\
\hline $10 \%$ & $25 \%$ & $55 \%$ & $10 \%$ & $0 \%$ & $5 \%$ & $15 \%$ & $65 \%$ & $15 \%$ & $0 \%$ \\
\hline
\end{tabular}

TABLE III: COMMUNICATION INITIATIVE

\begin{tabular}{|l|l|l|l|l|l|l|l|}
\hline \multirow{2}{*}{ Age } & pretest & somentimes & often & always & \multicolumn{2}{l|}{ somentimes } \\
\cline { 2 - 7 } & never & $50 \%$ & $0 \%$ & $0 \%$ & $50 \%$ & often \\
\hline 8 years & $50 \%$ & $33,3 \%$ & $16,7 \%$ & $33,3 \%$ & $33,3 \%$ & $50 \%$ \\
\hline 10 years & $16,7 \%$ & $0 \%$ & $0 \%$ & $71,4 \%$ & $14,3 \%$ & $50 \%$ \\
\hline 11 years & $33,3 \%$ & $0 \%$ & $33,3 \%$ & $33,3 \%$ & $33,3 \%$ & $57,1 \%$ \\
\hline
\end{tabular}

From the Table II and Table III, there is an improvement in students' ability to speak, improvement observed especially students who spoke little because there is an increase of this capacity in normal medium and posttest. A more accurate rendering of these results can be seen in the figure below:

Regarding the item about how students decide words, the results obtained are shown in the following table.

We see an improvement in this situation to give the students capacity of pronouncing sounds. It should be noted that many of the activities were focused on the ability of reference as mental deficiency generally goes hand in hand with various categories including dislalia language disorder 
is the most common.

Another item of the analysis refers to communication initiative of students with mental deficiencies. We believe it is interesting to analyze here the behavior of pupils according to their age.

From a simple analysis of the table we see an improvement in student achievement in each of the ages studied. Thus, if for students 8 years pretest communication initiative is divided equally (50-50\%) sometimes and sometimes. Among the variations in pretest they are all equal but sometimes variants often.[5] In other words, we believe that these students significantly improve their ability to take initiative in communication. Increase is observed in other cases, the most spectacular one gets old students. Next we used the chi square test to determine whether there are significant differences between pre and posttest and the results obtained are shown in Table IV

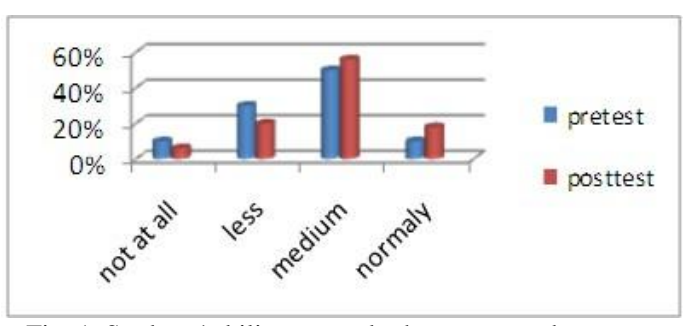

Fig. 1. Students' ability to speak, the pretest and posttest.

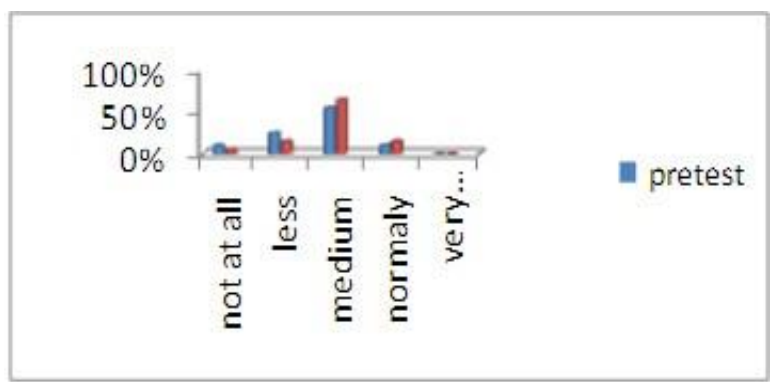

Fig. 2. Pronunciation students in speech

TABLE IV: COMPARISON OF FREQUENCIES IN TERMS OF COMMUNICATION INVOLVED IN PRE-AND POSTTEST

\begin{tabular}{|l|l|l|}
\hline Chi-Square & df & $\mathrm{p}$ \\
\hline 17,943 & 6 & .006 \\
& & \\
\hline
\end{tabular}

Threshold obtained is less than 0.05 and hence there are significant differences between the two phases of the experiment in terms of communication involving students with mental deficiency.

Another item considered is that of communication with peers, knowing that students with mental deficiencies hardly fail to communicate with their peers (see Table V).

TABLE V: COMMUNICATION WITH PEERS

\begin{tabular}{|c|c|c|c|c|c|c|c|c|c|}
\hline \multirow[t]{2}{*}{ Age } & \multicolumn{5}{|l|}{ pretest } & \multicolumn{4}{|c|}{ posttest } \\
\hline & never & $\begin{array}{l}\text { Some } \\
\text { times }\end{array}$ & $\begin{array}{l}\text { Some } \\
\text { times }\end{array}$ & often & always & $\begin{array}{l}\text { Som } \\
\text { times }\end{array}$ & $\begin{array}{l}\text { Some } \\
\text { times }\end{array}$ & often & always \\
\hline 8 ani & $50 \%$ & $50 \%$ & $0 \%$ & $0 \%$ & $0 \%$ & 0 & $50 \%$ & $50 \%$ & 0 \\
\hline 9 ani & $16,7 \%$ & $33,3 \%$ & 0 & $50 \%$ & 0 & $16,7 \%$ & $33,3 \%$ & $33,3 \%$ & $16,7 \%$ \\
\hline 10 ani & $28,6 \%$ & $14,3 \%$ & $42,9 \%$ & 0 & $14,3 \%$ & 0 & $57,1 \%$ & $28,6 \%$ & $14,3 \%$ \\
\hline 11 ani & $33,3 \%$ & 0 & $33,3 \%$ & $16,7 \%$ & $16,7 \%$ & $9,5 \%$ & $42,9 \%$ & $28,6 \%$ & $19,0 \%$ \\
\hline
\end{tabular}

What is observed from the first glance is that the pretest results do not appear at any age, to never version which means that the results of students in each age group were improved. After the experimental stage students are more willing to communicate, due first game we say who approached and made to be more willing to cooperate and work together. Or all of these can be achieved only through communication and in this case we compared the frequencies to see if the differences are significant, the results are given below (see Table VI).

The lower threshold in this case confirms the hypothesis proposed by us.

TABLE VI: COMPARISON OF FREQUENCIES IN TERMS OF COMMUNICATION \begin{tabular}{|l|l|l|} 
WITH PEERS IN PRETEST AND POSTTEST \\
\hline Chi-Square & $\mathrm{df}$ & $\mathrm{p}$ \\
\hline 29,546 & 12 & .003 \\
\hline
\end{tabular}

\section{CONCLUSIONS}

Assumption that we started this study, that the design and implementation of a therapeutic program which is based on the game will improve communication ability of students with mild and moderate mental deficiency is confirmed, resulting in the games that we have proposed are effective in educating students' communication and default recovery with mild and moderate mental deficiency. [6]

\section{A. The Limits of Research Can Be Mentioned}

- The low number of subjects involved in research.

- Short period of time the program was implemented therapeutic.

- Not all students were part of the same class and can therefore interfere subjective assessment of several key professors from observation.

\section{B. The Advantages Include}

- Research was conducted in a familiar environment students, their class or school;

- The person who carried out the experiment was also known to the students as they allowed a natural event

- Big attraction to students for activities, knowing that they prefer playing to all other activities

\section{We Intend to Continue Our Research by}

- Increasing the number of subjects and the research period.

- Finding and implementing games and other components of personality. 
- Making comparisons between different degrees of mental deficiency.[7]

\section{REFERENCES}

[1] I. Chelemen, Elemente de psihopedagogie specială, Editura Universităţii din Oradea, Oradea, 2010

[2] B. C. Buică, Bazele defectologiei, Editura Aramis, Bucureşti, 2004.

[3] I. Druțu, Studii şi cercetări în psihopedagogia specială, Editura Presa Universitară Clujeană, Cluj Napoca, 2002.

[4] V. Banciu, Jocul în activitățile de educare a limbajului, Editura Universității din Oradea, Oradea, 2012.

[5] K. Peter, D. Boros, and M. Herlaş, Jocul de rol ca modalitate de dezvoltare a copilului $\mathrm{cu}$ deficiență mintală moderată, în Marcu,V., Mentoratul -între profesiune şi artă, Fascicula Departamentului pentru pregătirea şi perfecționarea personalului didactic, Editura Universității din Oradea, Oradea, pp. 103-115, 2008.

[6] Clasificarea internațională a funcționării dizabilității şi sănătății (CIF), OMS, Geneva, Editura MarLink, Bucureşti, 2001.

[7] Manual de diagnostic și statistică a tulburărilor mentale (DSM IV. 1994), apărut sub egida Asociației Psihiatrilor Liberi din România, Bucureşti, 2000.

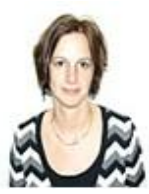

Karla Peter was born in Alesd, Bihor County, Romania on November 19, 1977. She graduated high school in 1997 at "Iosif Vulcan Highschool" for preprimary and primary teachers, Oradea. Than she attended the Faculty of Psychology from University of Oradea and she graduated in 2001. From 2012 she is PhD in Educational Sciences.

Her field of interest are the Psychopedagogy of mental disabled children, the psychopedagogy of children with learning disabilities, the Psychology of personality, Speech Therapy.

Mrs.Peter had published 5 books as single author or in cooperation and more than 30 studies in national or international reviews.

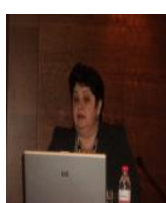

Viorica Banciu became a member of IERDC. Org. in September 2012. She was born in Sudrigiu, the commune of Rieni, the county of Bihor, Romania in August the $18^{\text {th }}$, 1962. She graduated highschool in 1980 at Ady Sincai, Cluj-Napoca, Romania and then attended the Faculty of Letters, Babes-Bolyai University. She graduated in 1989 becoming a teacher of English and Romanian. Viorica Banciu, doctor in philology in 2007.

Her fields of interest are English Literature, Children's Literature, Linguistics, English Language Teaching, Ethnic Studies, Gender Studies.

Current and previous research interests are linked to education and English Language Teaching for children with special educational needs and Children's Literature studies.

Dr. Viorica Banciu became associate professor of the University of Oradea in October, the first, 2012 and she is Member of International Editorial Advisory Board of PTSE- Practice and Theory is Systems of Education, Budapest, a journal specialized in education studies. 